\title{
Development of Student Worksheets as Online English Learning Media at the Indonesian Vocational School
}

\author{
Nurul Iskandar ${ }^{1}$, Mustaji $^{2}$, Miftakhul Jannah ${ }^{3}$

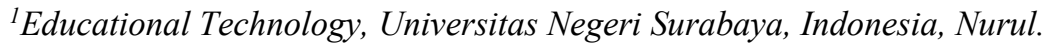 \\ ${ }^{2}$ Educational Technology, Universitas Negeri Surabaya, Indonesia, \\ ${ }^{3}$ Educational Technology, Universitas Negeri Surabaya, Indonesia,
}

\begin{abstract}
This study is to explore the development of student worksheets using Google forms in building student learning interests. Unfortunately, little is known from empirical literature about the use of Google forms as a medium of learning in Indonesian vocational schools. Purposive sample selection conducted to students in tenth grade at an Indonesian vocational school, precisely in the East Java district. Data collection techniques using interviews, observation, and questionnaires. Data were analysed by the triangulation method to ensure research results in drawing conclusions based on the validity of the data obtained. The findings of this research are deliberated in this paper.
\end{abstract}

Keywords - google form, students' worksheet, online learning

\section{INTRODUCTION}

\section{I.II. Applying the styles to an existing paper}

Online learning is an appropriate learning paradigm because it has both theoretical and practical appeal [1]. This learning has appeal for students based on some previous research because students no longer confined space, space, and time to learn [2]. However, to make students interested, several things need to be considered. Online learning participation has a category 1) has a complex process in the role and maintain relationships with others; 2) supported by physical and psychological tools; 3 ) not identical with speech and writing; and 4) supported by exciting activities [3].

On the contrary, online learning requires a lot of time and money [4]. From the above opinion, online learning is a learning that has theoretical and practical appeal without being bound by place, space, and time. Exciting activities must support it during the apprenticeship. The teacher facilitates students to be able to manage the thinking process and make students' psychology comfortable. Thus, online learning is not just a routine learning activity, but also can shape the critical thinking skills of students, particularly in English language learning.

The importance of developing and innovating the student worksheets is because the learning context requires a changes era. Notably, in vocational schools for learning purposes per the era, we face today. Hence, learning objectives can be achieved and scaffolded to overcome future learning problems. According to Reigeluth et al. (2016) [5], Student worksheets are scaffolding in the form of primary questions, information, instructions, or explanations. In preparing the student worksheets, the quality and quantity need to be considered. The scaffolding quality and quantity in learning must be tailored to the needs of students in the future, students' self-regulated skills, and the developmental needs of students through a combination of scaffolding from the teacher and peers [6]. The quality and quantity can affect student responses to the implementation of this learning. Worksheets were created to make it easier for teachers to conduct English learning online. Also, teachers pay attention to learning and content during the learning process [7]. The provision of scaffolding continues until students are indeed able to achieve their learning goals. Instruction and guidance should be given to achieve new milestones when students have difficulties in learning achievement [5]. The stipulation of scaffolding in the form of student worksheets must be engaging, especially in online learning. This study intends to explore the development of student worksheets in building students' thinking skills.

\section{LITERATURE REVIEW}

\section{II.I. Online learning and its obstacles in Indonesia}

The extent of globalisation is unstoppable in Indonesia. The era of the industrial revolution 4.0 demands on digital economic patterns, artificial intelligence, big data, robotic, and so on or known as the phenomenon of disruptive innovation. One of the impacts of the industrial era 4.0 in Indonesia is a policy changing in Indonesia. The policies include strategies and programs related to Higher Education science and technology resources, institutions, learning, and student affairs, as well as research and development as well as innovations [8]. The number of internet users based on data analysis from 2014 has reached around 74 million people, an increase from 2013 by 22 per cent [9].

The positive impact of online learning is that students can study anywhere and anytime [10]. Besides that, online learning is becoming a trend in schools in Indonesia using an online system [11]. It has been applied in schools, training, and universities because it is effective and efficient with an internet connection [12] [13]. However, some problems faced 
by students in Indonesia during online learning, namely 1) infrastructure problems (internet connection, electricity, and telephone), 2) software availability, 3) curriculum adjustment, 4) attitude toward Information Communication and Technology [14]. Therefore, Wang and Wu [15] suggested the need to consider the student's personalisation requirements to ensure that the technology we use achieved the desired results and increase the effectiveness of student learning. For long-term solutions, infrastructure improvements are needed to resolve connection problems to use e-Learning [16].

By knowing these developments, the presence of the internet in Indonesia is very influential as a new paradigm for learning models in schools. The use of internet technology to support learning activities is quite feasible to do in Indonesia. Internet connection prices are getting cheaper nowadays, which is indicated by the number of internet users in Indonesia continues to increase [17]. Thus, the importance of learning supported by IT and the internet has become popular in Indonesian schools.

\section{II.II. Student Worksheet}

The student worksheet is one of the supporting tools in learning that teachers can develop according to the situation and conditions of learning activities encountered [18]. Students' worksheets are studying devices that contain a series of questions and information designed to understand complex ideas accordingly; students can work on them systematically [19]. Student Worksheet is a sheet that contains the tasks that students must do, consisting of a title, essential competencies to be achieved, completion time, equipment needed, work steps, brief information, work is done, and reports [20]. It can be concluded that students' worksheets are a learning tool that contains questions and information in the form of sheets that students must be working on.

Furthermore, Prastowo defines that student worksheets are printed material in the form of sheets containing learning material, summaries, and instructions that students have to work [21]. In this study, student worksheets were not printed material but were made in electronic form. Student worksheets were prepared using google forms to achieve optimal online learning. Student worksheets can guide students in developing ideas for analysing and solving problems in a given assignment [19].

\section{II.III. Google Form}

Google continues to innovate from a variety of platforms it has, including Google Docs, one of which features also presents the Google form. Usually, Google Form is used for several things, such as creating a questionnaire, producing a quick count of opinions, online registration form, then managing it, and much more [22]. Research on the use of Google as a learning medium has been conducted by several researchers [23], [24], [25]. In this study, the main concern for developing student worksheets used was Google Form. The primary purpose of the development of student worksheets aided
Google form is to facilitate the performance of teachers and students in English language learning online. The main use of Google Forms is to collect data in real-time. The data obtained will be stored in Google Drive automatically. The teacher can give feedback to students automatically as well. Instead, students find it easier to fill in several questions contained in the worksheet. According to Iqbal et al., learning using Google form starts from the stages of planning, creating, publishing, and providing usage instructions [26]. Meanwhile, most students like the use of online questionnaires, which were considered to be easily accessible, efficient, saving paper, and attractive appearance. Hence, the study attempts to explore the following research question: 1) How is the students' characteristic? 2) How is the validity of the student worksheet? 3) How are students' responds in participating in online learning using google?

\section{METHODOLOGY}

This study has adopted a qualitative method. Data collection techniques using observation, interviews, and questionnaires. Interviews were conducted to attain data about the student's needs. At the same time, Questionnaires were used to collect data about the feasibility of worksheets and student responses to the use of spreadsheets since the strength of qualitative research lies in the process of triangulation [27]. Therefore, data analysis uses the triangulation method to draw conclusions based on the validity of the data obtained.

\section{III.I. Participants}

Thirty-one students from the tenth grade of vocational school were selected to experience learning about 'how to solve it.' The participants aged between sixteen dan seventeen. They were from accounting expertise programs with different schooling backgrounds. These students attended online English learning twice through their devices. Before learning, they had to have undertaken a pre-test. At the end of the learning activity, students carried out a post-test and filled out a questionnaire about their response to learning.

\section{III.II. Research Instruments}

Thirty-one The instruments used were interview sheets, observation sheets, and questionnaires. Interview sheets were used to obtain data directly from teachers in vocational schools about student characteristics and context. The first questionnaire was used to collect data from experts about the eligibility of student worksheets, and the second questionnaire was employed to obtain data from students about their responses to learning. The poll was made using a score at 4 Likert Scale: 1 (strongly disagree), 2 (disagree), 3 (agree), and 4 (strongly agree). 


\section{RESULTS AND DISCUSSION}

\section{IV.I. Student characteristic}

Characteristics of students are aspects or qualities of individual students, namely talent, learning motivation, and the initial ability of learning outcomes that they already have [28]. It is crucial to recognise the characteristics of students and the learning context to determine the quality of each individual as a guide in describing the strategy and selection of teaching materials. Base on Dick and Carey opinion [29], what is meant by analysing the characteristics of students is to learn the fundamental skills students have and what students need next. At the same time, context analysis to identify the place (classroom) that is used according to the conditions and characteristics of students. Following are the data obtained in analysing the characteristics of students in table 1 .

Table1. Analysis of Student Characteristics

\begin{tabular}{|c|c|c|c|}
\hline No & Category & Data Sources & Student Characteristics \\
\hline 1 & Entry skill & $\begin{array}{l}\text { Interview and obser- } \\
\text { vation }\end{array}$ & $\begin{array}{l}\text { - } \quad \text { There are } 31 \text { students (male and female). } \\
\text { Most students have learned about descriptive and } \\
\text { persuasive reading. } \\
\text { - } \quad \text { Most students have learned about recount reading. } \\
\text { Most have learned about reading a narrative. }\end{array}$ \\
\hline 2 & $\begin{array}{l}\text { Prior knowledge of the } \\
\text { topic area }\end{array}$ & $\begin{array}{l}\text { Interview and obser- } \\
\text { vation }\end{array}$ & $\begin{array}{l}\text { Most students lack in reading comprehension about } \\
\text { how to determine the topic of reading, determine the main } \\
\text { idea, word equation, determine the intentions and objectives } \\
\text { of the author, and conclude the contents of the passage. } \\
\text { Some students yet have no critical thinking skills, } \\
\text { including analysing problems, determining the author's } \\
\text { point of view, compiling supporting reasons, making deci- } \\
\text { sions, and assessing the content of reading. }\end{array}$ \\
\hline 3 & Attitude toward content & $\begin{array}{l}\text { Interview and obser- } \\
\text { vation }\end{array}$ & $\begin{array}{l}\text { - Some students have a high awareness of the im- } \\
\text { portance of mastering English as a communication tool. }\end{array}$ \\
\hline 4 & $\begin{array}{l}\text { Attitude toward potential } \\
\text { delivery system }\end{array}$ & $\begin{array}{l}\text { Interview and obser- } \\
\text { vation }\end{array}$ & $\begin{array}{l}\text { Students feel bored through the lecture and ques- } \\
\text { tion and answer method. } \\
\text { - } \quad \text { ual in class. } \\
\text { Students prefer web-based learning and audio-vis- } \\
\text { Students are interested in working in groups in } \\
\text { learning activities. }\end{array}$ \\
\hline 5 & Motivation & $\begin{array}{l}\text { Interview and obser- } \\
\text { vation }\end{array}$ & $\begin{array}{l}\text { - } \begin{array}{l}\text { Students have low learning motivation for English } \\
\text { subjects. }\end{array} \\
\text { Students do not have the desire to be able to under- } \\
\text { stand English reading. }\end{array}$ \\
\hline 6 & Educational and ability & $\begin{array}{l}\text { Interview and obser- } \\
\text { vation }\end{array}$ & $\begin{array}{l}\text { - } \\
\text { All students are at level X with Accounting exper- } \\
\text { tise competencies. } \\
\text { Student academic abilities are low, medium, and } \\
\text { high. No student who has a very high skill. }\end{array}$ \\
\hline 7 & $\begin{array}{l}\text { General group characteris- } \\
\text { tics }\end{array}$ & $\begin{array}{l}\text { Interview and obser- } \\
\text { vation }\end{array}$ & $\begin{array}{l}\text { Students have heterogeneous groups, students } \\
\text { come from different public and private high school (SMP), } \\
\text { and Madrasah Tsanawiyah (MTs) graduates. } \\
\text { Students have different social, economic, family, } \\
\text { and regional group backgrounds. }\end{array}$ \\
\hline
\end{tabular}

(adapted from Dick and Carey [29])

The results of the analysis of the characteristics of the students above showed that students' entry skills and fundamental knowledge were relatively low even though they had already studied descriptive, persuasive, recount, and narrative reading. It can be established that the advancement of learning tools and media is essential to increase students' interest and skills in learning English. Therefore, the expansion of 
Google Forms student worksheets is expected to increase student interest and expertise in understanding English lessons. Student worksheets are arranged based on topics with descriptive text type. Students' understanding of this vivid reading enables students to identify, analyse, and evaluate an object (humans, animals, and objects around the environment).

\section{IV.II. Research Expert validation on the student worksheet}

In the development of instructional materials, usually preceded by the validation of experts involved in the advancement of this instructional [29]. Therefore, before learning was done, Students' Worksheets were validated beforehand to experts. The purpose of expert validation is to determine the level of eligibility and get advice and recommendations before students' worksheets were distributed to students. Expert validation in this study was carried out by two experts, a learning technology expert, and an English learning expert. Expert validation was done by having the expert fill out the validation questionnaire sheet and provide suggestions and recommendations for students' worksheets that were developed. The results of the validation questionnaire were then converted into Table 2.

The results of expert validation on the expert assessment questionnaire sheet obtained an average number of 98 . If converted into a validation table, the developed student worksheet was included in the "outstanding" category. So, it can be concluded that based on the expert test results, the designed worksheet is valid and suitable to use in learning English. See Table 2.

Table 2. Scoring Conversion of Expert Validation

\begin{tabular}{|c|c|c|}
\hline Mark & Interval & Category \\
\hline $\mathrm{A}$ & $\mathrm{X} \geq 96.59$ & Very Good \\
\hline $\mathrm{B}$ & $78.20<\mathrm{X} \leq 96.59$ & Good \\
\hline $\mathrm{C}$ & $59.80<\mathrm{X} \leq 78.20$ & Enough \\
\hline $\mathrm{D}$ & $41.41<\mathrm{X} \leq 59.80$ & Poor \\
\hline $\mathrm{E}$ & $\mathrm{X}<41.41$ & Very Poor \\
\hline
\end{tabular}

Based on expert recommendations and suggestions, the student worksheet required improvements to the design of the cover. It needed more contrast colours composition on layout, tables should not be cut off for less spacing, and the expert concluded that student worksheet is suitable for use with revisions. Furthermore, the recommendations on the worksheet's content were content should be taken from the problems of daily life that are not structured. Issues can be made from media sources, both online or printed, to suit real-life conditions, and unstructured matters should be arranged based on news pieces, tables, graphs, and pictures.

The further revision came from the expert who checks on English learning materials. It was recommended that the worksheet display should contain an assessment rubric that accommodates the level of student skills on each assessment, and the expert suggested that the worksheet is valid and appropriate to use with minor revision. The experts impressed with a problem statement in the final task because it could make students have more critical thinking in solving problems. The worksheet content also helps students and teachers in the online English learning process.

\section{IV.III. Students' Perceptions}

The end result of the distribution of questionnaires to students $(n=31)$ as respondents in this study, students' perceptions of online English learning obtained using Google form students' worksheets were displayed in the following bar chart (Fig.1).

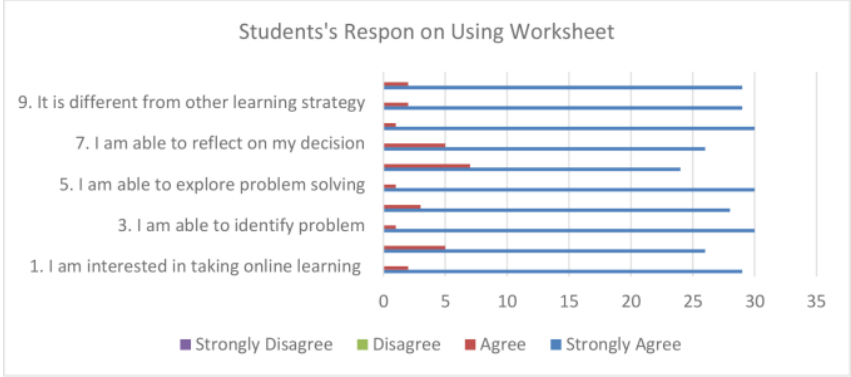

Fig. 1. Graph of Students' Response

Figure 1 shows the acquisition of data about students' responses to the use of students' online worksheets. Twentynine students were answering "strongly agree," and two students answering agree. They expressed interest in taking online learning. Twenty-six students answered, "strongly agree," and five students answered, "I agree". They stated that online learning made it easy for them to understand the lesson. Whereas there were 30 students answered strongly agree, and one student replied, "I agree." Hence, based on the responses, it shows that most students are always able to identify problems after using student worksheets. Twenty-eight students answered, "strongly agree," and three students answered to agree. They stated that they were able to define their learning goals after using the student worksheet.

Moreover, thirty students answered strongly agree, and one student chose, "I agree." From these responses, it shows that they can explore strategies in problem-solving. While, twenty-four students answered, "strongly agree," and seven students answered agree. They can use these strategies into the problems they face. Twenty-six students answered strongly agree, and five students answered, "I agree." Most of the students looked back to check whether the problem-solving strategy was right or wrong,

Furthermore, thirty students answered strongly agree, and one student answered, "I agree." The student worksheet creates a collaborative atmosphere in solving problems found in the student worksheet. While twenty-nine students answered strongly agree, and two students answered, "I agree." Most students stated that they felt online learning was different from the education they had experienced. Finally, twenty- 
nine students answered strongly agree, and two students answered to agree. Students learn to solve problems well. From these results, it is evident that an English form Google-assisted worksheet guides students in developing ideas for analysing and solving problems in a given assignment [19].

The Average of Students's Perception on ESW Online (percentage)

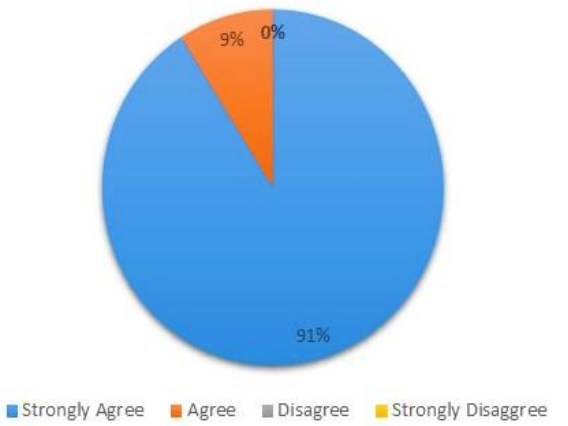

Fig. 2. Graph of the Average of Students' Respon on English Student Worksheet (ESW) Online

The graph above is a conclusion of the overall response of students to the use of online Student Worksheets. The results showed that as many as $91 \%$ stated strongly agree, and $9 \%$ agreed to use the Google form student worksheet online. This finding is coherent with, as reported in Ref. [30] that Google form performance had a positive effect on supporting English language learning. It can be concluded that some students were interested in using Student Worksheets in online learning. It is as stated in Ref. [31], students were satisfied with the Google form above average because it is easy to access, useful, interactive and communicative in learning activities. Likewise, the provision of scaffolding continues until students are indeed able to achieve their learning goals [5].

\section{CONCLUSION}

The study has contributions role for teachers of vocational schools in teaching English. It aroused students' critical thinking, problem-solving, communication, and collaboration. Students' worksheet aided Google form is useful for teaching and learning English online. It was remarkable for teaching and learning English. It practised students learn how to solve a problem, especially reading. It is useful for the teacher to enhance students' critical thinking. The findings show that after using Google Forms-assisted worksheets, many students improve their critical thinking. The problem presented in the sheet is ill-structured. Students also have the opportunity to communicate and collaborate with them. However, it demanded hard work for the teacher as an instructional designer. It spent more time constructing relevant students' worksheets to students and learning needs. The teacher can develop this student worksheet by adjusting the learning content and characteristics of students.

\section{REFERENCES}

[1] Shalev-Shwartz S. Online learning and online convex optimization. Foundations and trends in Machine Learning. 2011 Feb;4(2):107-94.

[2] Zhao K, Yang Q, Ma X. Exploration of an open online learning platform based on google cloud computing. International Journal of Emerging Technologies in Learning (iJET). 2017 Jul 12;12(07):17-31.

[3] Hrastinski S. A theory of online learning as online participation. Computers \& Education. 2009 Jan 1;52(1):78-82.

[4] Rice S, McKendree J. "e-Learning," in Understanding Medical Education: Evidence, Theory and Practice, 2nd Edition. ISBN: 978-1-118-47238-5, Jamaica, Wiley-Blackwell. 2013: p. 161.

[5] Reigeluth CM, Beatty BJ, Myers RD, editors. Instructional-design theories and models, Volume IV: The learner-centered paradigm of education. Routledge; 2016 Jul 22.

[6] Watson WR, Watson SL. "Principles for Personalized Instruction," in Instructional-Design Theories and Models (Volume IV): The Learner-Centered Paradigm of Education. ISBN: 978-1-138-01293-6, New York, Routledge. 2016: p. 180.

[7] Anggraini R, Wahyuni S, Lesmono AD. Pengembangan lembar kerja siswa (Lks) berbasis keterampilan proses di SMAN 4 Jember. Jurnal Pembelajaran Fisika. 2016 Mar 1;4(4):350-65.

[8] Ambarwatia A, Florentinus TS, Rusdarti R, Rifai A. Tantangan Guru Madrasah di Abad 21: Peningkatan Sumber Daya Manusia Guru Madrasah Berbasis Diklat di Era 4.0. InProsiding Seminar Nasional Pascasarjana (PROSNAMPAS) 2019 (Vol. 2, No. 1, pp. 71-77).

[9] Fatanti MN. Twitter dan Masa Depan Politik Indonesia: Analisis Perkembangan Komunikasi Politik Lokal Melalui Internet. Jurnal Ilmu Pengetahuan dan Teknologi Komunikasi. 2014 Jun;16(1):17-30.

[10] Suharmawan W, Herawati IE. Teknologi Informasi dan Komunikasi dalam Proses Pembelajaran. Al-Ishlah: Jurnal Studi Pendidikan Articles. 2015;13(2):143-153.

[11] Syaputra HF. Sistem Informasi E-learning di Sekolah. Jurnal Ilmu Pengetahuan dan Teknologi Komputer. 2017;2(2): 60-65.

[12] Anshori S. Pemanfaatan Teknologi Informasi Dan Komunikasi Sebagai Media Pembelajaran. CivicCulture : Jurnal Ilmu Pendidikan PKN Dan Sosial Budaya. 2019;2(1):88-100.

[13] Abdillah LA, Rofiq AA, Indriani DE. Information Technology Utilization in Environmentally Friendly Higher Education. in In Proceedings of the Built Environment, Science and Technology International Conference. 2018; 1: BEST ICON, ISBN 978-989-758- 
International Journal of Engineering Research and Technology. ISSN 0974-3154, Volume 13, Number 11 (2020), pp. 3819-3824

(C) International Research Publication House. https://dx.doi.org/10.37624/IJERT/13.11.2020.3819-3824

414-5, pages $\quad$ 350-355. DOI: 10.5220/0008908303500355, Surabaya, Indonesia,.

[14] Haron H, Aziz NH, Harun A. A Conceptual Model Participatory Engagement Within E-learning Community. Procedia computer science. 2017 Jan 1;116:242-50.

[15] Wang SL, Wu CY. Application of context-aware and personalized recommendation to implement an adaptive ubiquitous learning system. Expert Systems with applications. 2011 Sep 1;38(9):10831-8.

[16] Kusumo NS, Kurniawan FB, Putri NI. eLearning Obstacle Faced by Indonesian Students. InThe Eighth International Conference on eLearning for KnowledgeBased Society 2012 Feb.

[17] Pujilestari Y. Dampak Positif Pembelajaran Online Dalam Sistem Pendidikan Indonesia Pasca Pandemi Covid-19. 'ADALAH. 2020 Apr 19;4(1).

[18] Widjajanti E. Pelatihan penyusunan LKS mata pelajaran kimia berdasarkan kurikulum tingkat satuan pendidikan bagi guru SMK/MAK. Makalah dipresentasikan pada Kegiatan Pengabdian pada Masyarakat di FMIPA UNY. 2008;22.

[19] Choo SS, Rotgans JI, Yew EH, Schmidt HG. Effect of worksheet scaffolds on student learning in problembased learning. Advances in health sciences education. 2011 Oct 1;16(4):517.

[20] Ekantini A, Wilujeng I. The Development of Science Student Worksheet Based on Education for Environmental Sustainable Development to Enhance Scientific Literacy. Universal Journal of Educational Research. 2018;6(6):1339-47.

[21] Prastowo A. Menyusun Rencana Pelaksanaan Pembelajaran (RPP) Tematik Terpadu: Implementasi $\mathrm{Ku}-$ rikulum 2018 Untuk SD/MI. Kencana; 2017.

[22] Eril. Mengenal Google Form: Pengertian, Kegunaan dan Pembuatan. Qwords. 2020. [Online]. Available: https://qwords.com/blog/mengenal-google-form/.

[Accessed 22 July 2020].
[23] Graham MJ, Borgen J. Google Tools Meets Middle School. 2018. DOI:http://dx.doi.org/10.4135/9781506360188, California: Corwin.

[24] Iqbal M, Simarmata J, Feriyansyah F, Tambunan ARS, Sihite O, Gandamana A, Eza GN, Kurniawan F, Asiah A, Rozi F, Faisal F, Manurung IFU, Ihwani M, Nathan PLA. Using Google form for student worksheet as learning media. International Journal of Engineering \& Technology. 2018;7(3.4): 321-324. DOI: 10.14419/ijet.v7i2.29.13646,

[25] Ahmed BES. Social Media in Teaching of Languages. International Journal of Emerging Technologies in Learning. $\quad 2020 ; 15(12)$ : 72-80. DOI: https://doi.org/10.3991/ijet.v15i12.12645,.

[26] Iqbal M, Rosramadhana R, Amal BK, Rumapea ME. Penggunaan Google Forms Sebagai Media Pemberian Tugas Mata Kuliah Pengantar Ilmu Sosial. Jupiis: Jurnal Pendidikan Ilmu-Ilmu Sosial. 2018;10(1):120-7.

[27] Bachri BS. Meyakinkan validitas data melalui triangulasi pada penelitian kualitatif. Jurnal Teknologi Pendidikan. 2010 Apr 1;10(1):46-62.

[28] Degeng IN, Sudana N. Ilmu pengajaran taksonomi variabel. Jakarta: Depdikbud. 1989.

[29] Dick W, Carey L, Carey JO. The systematic design of instruction. 6th, Boston: MA, 2015.

[30] Sihotang DO. Optimalisasi Penggunaan Google Class Room Dalam Peningkatan Minat Belajar Bahasa Inggris Siswa Di Era Revolusi Industri 4.0 (Studi Kasus Di Smk Swasta Arina Sidikalang). Jurnal Teknologi Kesehatan Dan Ilmu Sosial (Tekesnos). 2019;1(1):7781.

[31] Shaharanee INM, Jamil JM, Rodzi SSM. The application of Google form as a tool for teaching and learning. Journal Telecommunication, Electronic and Computing Engineering. 2016;8(10): 5-8.

\begin{abstract}
Authors
Nurul Iskandar is a student of postgraduate doctoral program in state university of Surabaya since 2017 until now. His major program is educational technology. His current job is an English teacher of Vocational school of Blega in Bangkalan. The focus of his research interest is in the field of Instructional Design, precisely in Problem Based Learning and His interest is in designing instructional for vocational school, especially in English lesson.

Mustaji is a lecturer at the State University of Surabaya. Currently, he is the head of Educational Technology study program in post-graduate school of UNESA. From 2014 to 2016, he played an active role in research activities at ministry of research and education programs.
\end{abstract}

Miftakhul Jannah is a lecturer at the State University of Surabaya. The focus of her research interest is in the field of education, where some of her works was presented at conferences and published in accredited scientific journals. She also won several research funding from Indonesian ministry of research and education. 